\title{
26. The Results and the Pendulum
}

\author{
Malcolm Mackerras
}

The two most interesting features of the 2010 election were that it was close and it was an early election. Since early elections are two-a-penny in our system, I shall deal with the closeness of the election first. The early nature of the election does, however, deserve consideration because it was early on two counts. These are considered below. Of our 43 general elections so far, this was the only one both to be close and to be an early election.

Table 26.1 Months of General Elections for the Australian House of Representatives, 1901-2010

\begin{tabular}{|l|c|l|}
\hline Month & Number & Years \\
\hline March & 5 & $1901,1983,1990,1993,1996$ \\
\hline April & 2 & 1910,1951 \\
\hline May & 4 & $1913,1917,1954,1974$ \\
\hline July & 1 & 1987 \\
\hline August & 2 & 1943,2010 \\
\hline September & 4 & $1914,1934,1940,1946$ \\
\hline October & 6 & $1929,1937,1969,1980,1998,2004$ \\
\hline November & 7 & $1925,1928,1958,1963,1966,2001,2007$ \\
\hline December & 12 & $\begin{array}{l}1903,1906,1919,1922,1931,1949,1955,1961,1972, \\
\end{array}$ \\
\hline Total & 43 & \\
\hline
\end{tabular}

\section{The Close Election}

In the immediate aftermath of polling day, several commentators described this as the closest election in Australian federal history. While I can see why people would say that, I describe it differently. As far as I am concerned, there have been 43 general elections for our House of Representatives of which four can reasonably be described as having been close. They are the House of Representatives plus half-Senate elections held on 31 May 1913, 21 September 1940, 9 December 1961 and 21 August 2010. There has, in my analysis, never been a close doubledissolution election or one for the House of Representatives only.

The 1913 and 1961 elections did not produce a hung parliament. They were so close, however, as to result in the early dissolution of the 5th Parliament and the 24th Parliament respectively. The 1940 election did produce a hung parliament, 
which ran its full term. (For a discussion of the expression 'full term', see below.) Eventually, we shall discover the history of the 43rd Parliament. My guess is that it will run to a full term, as did the 16th Parliament, elected in 1940.

Born in 1939, and professionally employed in politics since 1959, I have very good memories of December 1961 and August 2010. There are, in my opinion, two important differences. In 1961 two seats were very closely contested: Moreton, won by the Liberal Party, and Evans, won by Labor. In 2010 none was. For that reason, I consider 1961 to have been closer than 2010. More importantly, perhaps, the closeness of the 1961 election came as a complete shock. In contrast, in 2010 we had a predicted close election. I have been through the 2010 pollingday predictions of the experts. Every recognised analyst predicted a close result.

For 1913 and 1940, I must rely on the journalists of the day. For example, A. N. Smith wrote a magnificent book, Thirty Years: The Commonwealth of Australia, 1901-1931, which was published in Melbourne in 1933. Referring to the defeat of Andrew Fisher's Labor Government, he wrote, on pages 129 and 130:

The elections took place on 31st May and were singularly inconclusive. The early counting showed that the party numbers in the House of Representatives were likely to be almost equal. For several days the result depended upon the counting of votes from the outer districts of two widely scattered electorates of New South Wales. In the Riverina Division the retiring Labor member was fiercely assailed by a strong opponent. In the adjoining Hume Division the veteran Sir William Lyne, who had supported the Labor Government, was also on the defence. The final returns were against both and the seats went to the Opposition. Against these was to be set Ballarat, vacated by Mr. Deakin, where, after a similar close contest, the seat went to Labor by a small majority.

After ten or twelve days of doubt the Labor Party lost command of the House of Representatives by one member. Its losses included five seats in New South Wales and four in Victoria. But it won Bendigo from Sir John Quick, who had been a member of the Federal Convention, and to whom Federation owed so much, and also seats in Queensland, South Australia and Western Australia. The Liberals secured 38 seats against 37 gained by the Labor Party.

The records tell us that the second term of the Fisher Government ran from 29 April 1910 to 24 June 1913. More importantly, they tell us that in Hume the votes were 11575 for Robert Patten (Liberal) and 11236 for Sir William Lyne. In Riverina the votes were 11674 for Franc Brereton Sadleir Falkiner (Liberal) and 11208 for the sitting Labor Member, John Moore Chanter. These were close results but they were not nearly as close as Moreton in 1961. For that reason, I 
consider the 1961 election to have been closer than in 1913. The 5th Parliament first met on 9 July 1913 and was dissolved on 30 July 1914, so its length was one year and 21 days. Thus, here was a case of an early dissolution: a double dissolution.

The circumstances of the 1940 election are best described by Don Whitington in his book The House will Divide, which was first published in Melbourne in 1954. In his Chapter 9, 'The Menzies governments: 1939-1940', he writes:

Just before the 1940 elections three senior ministers - the Army Minister, G. A., Street; the Vice President of the Executive Council, Sir Henry Gullett; and the Minister for Air, J. V. Fairbairn, were killed in an air crash near Canberra. It was alleged, but never proved, that Fairbairn was flying the machine, a service aircraft, as it approached Canberra airport to land. This was the worst misfortune the Government had experienced, for all three were capable ministers, and all were administering departments directly connected with the war effort.

Worse was to follow, from Menzies' point of view, because at the general election in September 1940 the Government lost its majority. Government and Labor parties were returned with 36 each, two Independents holding the balance of power. Thus was ushered in what was probably the most fantastic era in Australian politics, an era in which the Commonwealth had a Government depending for survival on the votes of two Independents, but with elements within its own ranks which were not prepared to subjugate personal ambitions and prejudices to the prosecution of the war. (Whitington 1954, 73)

On page 74, in Chapter 10, 'Twelve months' turmoil', Whitington writes:

As sometimes happens in politics, the minor issues of the 1940 election, which were virtually ignored, were more significant than the events which occupied the public eye.

Not until the election was over, for instance, was the full importance appreciated of the two men who held the balance of power in the new Parliament. One was A. W. Coles, one of two brothers who had created what was by then one of the biggest chain store organizations in Australia; the other was Alex Wilson, a Victorian wheat farmer of the post World War I era, who, like most of his fellows, had financial dealings with the private banks about which he retained a sense of grievance.

Coles entered the Parliament as the Independent member for the Victorian seat of Henty, but joined the U. A. P. [United Australia 
Party] about eight months later. Wilson was elected as an Independent Country Party candidate, and announced that he would support the Government, though it was known his support would be conditional on the Government meeting his wishes on a number of matters, particularly financial policy.

Menzies lost the office of Prime Minister to Arthur Fadden on 29 August 1941. Then the Fadden Government was defeated in the House of Representatives on a vote described by Whitington in Chapter $10(1954,84-85)$ as follows:

Curtin moved: 'That while agreeing that the expenditure requisite for the maximum prosecution of the war should be provided by Parliament, the Committee is opposed to unjust methods prescribed by the Budget, declares that they are contrary to equality of sacrifice, and directs that the plan of the Budget should be recast to ensure a more equitable distribution of the national burden.'

Curtin knew - though few others did - that he would have the support of both Coles and Wilson. In a brief speech, Coles said: 'I regard the proposal of the Leader of the Opposition as a motion of want of confidence in the Government. [There is]...a loss of confidence in the Government's ability to carry on and to wage the maximum war effort. I told the Prime Minister I would vote against this Government today because he cannot give any assurance to the Parliament. He gave to the Governor-General an assurance he was not justified in giving because he had not consulted me. I told those Ministers who approached me when the ex-Prime Minister was being removed that I would not stand for it and that I would not support the Government.'

Wilson said he would support Labor also because he disapproved of the Government's financial policy.

Curtin's amendment was carried, and the Government resigned. Nairn, the U. A. P. Speaker, agreed to carry on under Labor, which gave it an extra vote in the House. The Curtin Cabinet was sworn in on October 7, 1941.

The truly interesting feature of the 16th Parliament is that it remained (until 2010) the sole hung parliament of the past 100 years. Yet it lasted for a full term of three years. Part of the reason for this stability was that there was a change of government during the term.

I remember the 1961 election very well indeed. From October 1959, I was a research officer with the Federal Secretariat of the Liberal Party and on polling night in 1961 I went into the tally room in Canberra with the same attitude as 
everybody else: Menzies was going to win, probably with minimal losses of seats. Menzies was a political genius who had always won bigger than expected so the same would happen again. There was only one opinion poll at the time. Released on Thursday, 7 December, it showed 47 per cent intending to vote Liberal-Country Party, 47 per cent for Labor and 6 per cent for the anti-Labor Democratic Labor Party (DLP) - a result that, in two-party preferred terms, represented an electorate dividing nearly 53-47 per cent in favour of Menzies. In other words, the swing to Labor was predicted to be only a little more than 1 per cent.

The polls closed at $8 \mathrm{pm}$ in those days, and I gathered in the small tally room with the then Federal Director, Bob Willoughby. We were a bit shocked that Wide Bay was early looking like a loss to Labor, but it was a Country Party seat! We could not believe the figures being posted for Cowper where Sir Earle Page looked to be in trouble. In our disbelief, we asked Frank Ley, the Chief Electoral Officer, to check the Cowper figures, which, we thought, could not possibly be correct. Ley assured us they were correct. Anyway Cowper, like Wide Bay, was also a Country Party seat!

Willoughby was a bit disappointed at the emerging picture but he displayed no sign of recognising the danger to the government. The Sun-Herald on 10 December ran the headline 'LIBS BACK, but with a reduced majority'. Arthur Calwell was reported to have conceded defeat to reporters at $11 \mathrm{pm}$ on election night. Late on that Sunday, Willoughby and I did some figure work and concluded that the probable result was a 61-61 seat draw. The press did not, however, seem fully to understand. The Monday-morning headline in the Sydney Morning Herald was 'Swing against Menzies grows', but the paper believed the government had been returned. In The Canberra Times, the swing was noted but ' $[\mathrm{t}]$ he government will, however, retain a working majority in the House of Representatives'.

In our belief that the result would be a 61-61 draw, we were convinced there would have to be another election. If the Liberal Party agreed to provide the speakership then it would give Labor a one-seat majority. Anyway, on 18 December the result became known. The seat of Moreton in Queensland was retained by Jim Killen and the result was 62-60 in favour of Menzies.

I consider 1961 to have been our closest election so I explain by comparing Moreton in 1961 with Corangamite in 2010. In the Moreton case the final win by Killen was with a majority of 130 votes: 26239 for Killen (Liberal) and 26109 for O'Donnell (Labor). In percentage terms that was 50.12 per cent for Killen and 49.88 per cent for $\mathrm{O}^{\prime}$ Donnell. In the Corangamite case, the final win by Darren 
Cheeseman was with a majority of 771 votes: 47235 for Cheeseman (Labor) and 46464 for Sarah Henderson (Liberal). In percentage terms that was 50.41 per cent for Cheeseman and 49.59 per cent for Henderson.

The close 1961 and 2010 elections make for an interesting comparative exercise, with party roles reversed. In both cases a Queensland anti-government landslide nearly brought the government down. In both cases, however, Victoria saved the government. In both cases, the system of compulsory preferences saved the party in power. In 1961 the 80-20 distribution of DLP preferences in favour of the Coalition saved the Liberal Party the seats of Bennelong (NSW), Bruce (Vic.), Maribyrnong (Vic.) and Moreton (Qld) where Labor candidates led on the primary vote. In 2010 the 80-20 distribution of the preferences of the Greens in favour of Labor saved them the seats of Banks, Reid and Robertson in New South Wales, Corangamite, Deakin and La Trobe in Victoria and Lilley and Moreton in Queensland where Liberal candidates led on the primary vote.

The contrasts between the cases are, first, between a long-term Liberal prime minister (Bob Menzies) saved by the system and a short-term Labor prime minister (Julia Gillard) equivalently saved. Second, the Menzies 62-60 win gave him majority government, but the Gillard 76-74 win gave her only minority government. Against that it should be noted (see Table 26.5) that the Menzies Government failed to win a majority of the two-party preferred vote in 1961 whereas the Gillard Government succeeded in that respect in 2010.

The 24th Parliament first met on 20 February 1962 and was dissolved on 1 November 1963, so its length was one year, eight months and 13 days. The November 1963 general election was for the House of Representatives only, accompanied by one Senate casual vacancy election in Queensland. The 43rd Parliament first met on 28 September 2010 and we shall find out its history soon enough. I feel sure it will run full term.

\section{The Early Election}

To the best of my knowledge, I am the only person who has ever defined the term 'early election' and I shall do that below. In the meantime, I want to say something about the date 21 August, the date sensibly chosen by Julia Gillard. During the 1940s there were four general elections for the House of Representatives accompanied by the normal periodical election for half the Senate. They were held on 21 September 1940, 21 August 1943, 28 September 1946 and 10 December 1949. So the calendars for 1943 and 2010 were identical. Both in 1943 and again in 2010, the elections were the earliest in terms of the time distance from the expiry of the terms of existing senators - namely, 30 
June 1944 and 30 June 2011. In 1943 the Australian people replaced a hung parliament with a Labor-majority parliament. In 2010 they did the reverse of that.

It is worth noticing that the Curtin election of 21 August 1943 was a one-option vote. There were no double-dissolution 'triggers' in 1943 so Curtin had to make it for the House of Representatives and half the Senate. In contrast, Gillard had a choice not available to Curtin: with 14 'trigger' bills on the list (11 of which related to the carbon pollution reduction scheme), there could have been a double dissolution. In the end, however, she made the same choice as Curtin. There have been three winter elections - all called by Labor prime ministers. The third was the double-dissolution election held on 11 July 1987, called by Bob Hawke. For a full list of the months of elections, see Table 26.1. That table leads me to predict that the next election will be in October 2013.

When I say I am the only person who has ever defined the term 'early election', I am referring to my article in Politics for May 1984 (Mackerras 1984, 73-84). In that article, I defined an early election as one that results from an early dissolution of the House of Representatives. I have kept that article up to date and the current version of it can be found on the web site of Old Parliament House where, now retired at the age of seventy-two, I am a volunteer guide.

The term 'early dissolution' is defined by me to be any dissolution occurring other than in the last six months of the life of the parliament. By definition, therefore, every double-dissolution election is an early election. Consequently, 2010 was self-evidently early. We know that because we know the doubledissolution option was available. So the three winter elections give us two early cases (1987 and 2010) and one case when the election was not early: 1943.

This was our forty-third general election for the House of Representatives and our nineteenth early election. The early elections were held in December 1903, September 1914, May 1917, December 1919, October 1929, December 1931, September 1934, April 1951, December 1955, November 1963, May 1974, December 1975, December 1977, March 1983, December 1984, July 1987, March 1990, October 1998 and August 2010.

In my article referred to above, I have a table entitled 'Early Dissolutions of the House of Representatives' in which I give all the information one needs to know. For the purpose of this chapter, the critical information is the length of the term and the reason to dissolve early. Without going into too much needless detail, I notice that the length of the first Lyons Parliament was two years, five months and 22 days, the first ('elected') Menzies Parliament, one year and 25 days, the third Menzies Parliament, one year, three months and one day, the sixth Menzies Parliament, one year, eight months and 13 days, the first Whitlam 
Parliament, one year, one month and 15 days, the second Whitlam Parliament, one year, four months and two days, the first Fraser Parliament, one year, eight months and 25 days, the third Fraser Parliament, two years, two months and 10 days, the first Hawke Parliament, one year, six months and five days, the second Hawke Parliament, two years, three months and 16 days, the third Hawke Parliament, two years, five months and five days, the first Howard Parliament, two years and four months, and the Rudd-Gillard Parliament, two years, five months and seven days. Notice the striking similarity between the first Lyons Parliament and the Rudd-Gillard Parliament.

More interesting than the above, however, is the reason given by each prime minister for the early dissolution. The reason 'to preserve/restore simultaneous elections with the half-Senate' accounts for six cases: 1903, 1917, 1955, 1977, 1984 and 1990. Section 57 dissolutions (double dissolutions) also account for six cases: 1914, 1951, 1974, 1975, 1983 and 1987. There are three cases of the need for a new mandate for policies - 1919, 1934 and 1998 - and three cases coming under the heading 'instability in the House of Representatives': 1929, 1931 and 1963.

That left just one case for which I needed a description: the dissolution occurring on 19 July 2010. Gillard did not give one so I entered this as the reason: 'to enable Julia Gillard to become an elected prime minister.' I placed the term 'elected prime minister' in inverted commas.

Table 26.2 House of Representatives: Seats won, 24 November 2007 general election - actual

\begin{tabular}{|l|c|c|c|c|c|}
\hline State/Territory & Labor & Liberal & Nationals & Independent & Total \\
\hline New South Wales & 28 & 15 & 5 & 1 & 49 \\
\hline Victoria & 21 & 14 & 2 & - & 37 \\
\hline Queensland & 15 & 10 & 3 & 1 & 29 \\
\hline Western Australia & 4 & 11 & - & - & 15 \\
\hline South Australia & 6 & 5 & - & - & 11 \\
\hline Tasmania & 5 & - & - & - & 5 \\
\hline Australian Capital Territory & 2 & - & - & - & 2 \\
\hline Northern Territory & 2 & - & - & - & 2 \\
\hline Total & 83 & 55 & 10 & 2 & 150 \\
\hline
\end{tabular}


Table 26.3 House of Representatives: Seats won, 24 November 2007 general election-notional (including Lyne by-election)

\begin{tabular}{|l|c|c|c|c|c|}
\hline State/Territory & Labor & Liberal & Nationals & Independent & Total \\
\hline New South Wales & 30 & 12 & 4 & 2 & 48 \\
\hline Victoria & 21 & 14 & 2 & - & 37 \\
\hline Queensland & 17 & 9 & 3 & 1 & 30 \\
\hline Western Australia & 5 & 10 & - & - & 15 \\
\hline South Australia & 6 & 5 & - & - & 11 \\
\hline Tasmania & 5 & - & - & - & 5 \\
\hline Australian Capital Territory & 2 & - & - & - & 2 \\
\hline Northern Territory & 2 & - & - & - & 2 \\
\hline Total & 88 & 50 & 9 & 3 & 150 \\
\hline
\end{tabular}

Table 26.4 House of Representatives: Seats won, 21 August 2010 general election-actual

\begin{tabular}{|l|c|c|c|c|c|c|}
\hline & Labor & Liberal & Nationals & Independent & Greens & Total \\
\hline New South Wales & 26 & 16 & 4 & 2 & - & 48 \\
\hline Victoria & 22 & 12 & 2 & - & 1 & 37 \\
\hline Queensland & 8 & 16 & 5 & 1 & - & 30 \\
\hline Western Australia & 3 & 11 & 1 & - & - & 15 \\
\hline South Australia & 6 & 5 & - & - & - & 11 \\
\hline Tasmania & 4 & - & - & 1 & - & 5 \\
\hline Australian Capital Territory & 2 & - & - & - & - & 2 \\
\hline Northern Territory & 1 & 1 & - & - & - & 2 \\
\hline Total & 72 & 61 & 12 & 4 & 1 & 150 \\
\hline
\end{tabular}

Table 26.5 Aggregate Two-Party Preferred Percentages, 1940-2010

\begin{tabular}{|l|c|c|c|}
\hline Election & Percentage Labor & $\begin{array}{c}\text { Percentage } \\
\text { UAP-Lib.-CP-Nats }\end{array}$ & Percentage swing \\
\hline $1940^{\text {a }}$ & 50.3 & 49.7 & 0.9 to Labor \\
\hline $1943^{\text {a }}$ & 58.2 & 41.8 & 7.9 to Labor \\
\hline $1946^{\text {a }}$ & 54.1 & 45.9 & 4.1 to Lib.-CP \\
\hline $1949^{a}$ & 49.0 & 51.0 & 5.1 to Lib.-CP \\
\hline $1951^{\text {a }}$ & 49.3 & 50.7 & 0.3 to Labor \\
\hline $1954^{a}$ & 50.7 & 49.3 & 1.4 to Labor \\
\hline $1955^{\text {a }}$ & 45.7 & 54.3 & 5.0 to Lib.-CP \\
\hline $1958^{a}$ & 45.9 & 54.1 & 0.2 to Labor \\
\hline $1961^{\text {a }}$ & 50.5 & 49.5 & 4.6 to Labor \\
\hline $1963^{a}$ & 47.4 & 52.6 & 3.1 to Lib.-CP \\
\hline $1966^{\text {a }}$ & 43.1 & 56.9 & 4.3 to Lib.-CP \\
\hline $1969^{a}$ & 50.2 & 49.8 & 7.1 to Labor \\
\hline $1972^{\text {a }}$ & 52.7 & 47.3 & 2.5 to Labor \\
\hline
\end{tabular}




\begin{tabular}{|l|c|c|c|}
\hline Election & Percentage Labor & $\begin{array}{c}\text { Percentage } \\
\text { UAP-Lib.-CP-Nats }\end{array}$ & Percentage swing \\
\hline $1974^{\mathrm{a}}$ & 51.7 & 48.3 & 1.0 to Lib.-CP \\
\hline $1975^{\mathrm{a}}$ & 44.3 & 55.7 & 7.4 to Lib.-CP \\
\hline $1977^{\mathrm{a}}$ & 45.4 & 54.6 & 1.1 to Labor \\
\hline $1980^{\mathrm{a}}$ & 49.6 & 50.4 & 4.2 to Labor \\
\hline $1983^{\mathrm{b}}$ & 53.2 & 46.8 & 3.6 to Labor \\
\hline $1984^{\mathrm{b}}$ & 51.8 & 48.2 & 1.4 to Lib.-Nats \\
\hline $1987^{\mathrm{b}}$ & 50.8 & 49.2 & 1.0 to Lib.-Nats \\
\hline $1990^{\mathrm{b}}$ & 49.9 & 50.1 & 0.9 to Lib.-Nats \\
\hline $1993^{\mathrm{b}}$ & 51.4 & 48.6 & 1.5 to Labor \\
\hline $1996^{\mathrm{b}}$ & 46.4 & 53.6 & 5.0 to Lib.-Nats \\
\hline $1998^{\mathrm{b}}$ & 51.0 & 49.0 & 4.6 to Labor \\
\hline $2001^{\mathrm{b}}$ & 49.1 & 50.9 & 1.9 to Lib.-Nats \\
\hline $2004^{\mathrm{b}}$ & 47.3 & 52.7 & 1.8 to Lib.-Nats \\
\hline $2007^{\mathrm{b}}$ & 52.7 & 47.3 & 5.4 to Labor \\
\hline $2010^{\mathrm{b}}$ & 50.1 & 49.9 & 2.6 to Lib.-Nats \\
\hline
\end{tabular}

Notes: ${ }^{a}$ In respect of the 17 general elections from 1940 to 1980 (inclusive), the statistics are from estimates of the two-party preferred vote; ${ }^{b}$ in respect of the 11 general elections from 1983 to 2010 (inclusive), the statistics are the percentages of the actual two-party preferred vote aggregates.

\section{Table 26.6 Labor's Two-Party Preferred Percentages at Winning Elections}

\begin{tabular}{|l|c|c|c|}
\hline Election & Winner & Incumbent prime minister? & Percentage Labor \\
\hline 1943 & Curtin & Yes & 58.2 \\
\hline 1946 & Chifley & Yes & 54.1 \\
\hline 1983 & Hawke & No & 53.2 \\
\hline 2007 & Rudd & No & 52.7 \\
\hline 1972 & Whitlam & No & 52.7 \\
\hline 1984 & Hawke & Yes & 51.8 \\
\hline 1974 & Whitlam & Yes & 51.7 \\
\hline 1993 & Keating & Yes & 51.4 \\
\hline 1987 & Hawke & Yes & 50.8 \\
\hline 2010 & Gillard & Yes & 50.1 \\
\hline 1990 & Hawke & Yes & 49.9 \\
\hline
\end{tabular}




\section{House Seat Gains and Losses in 2010}

In 1961, 1963, 1966 and 1969 seats in the House of Representatives changed hands only in one direction. In 1961 Labor gained 15 seats and lost none. In 1963 and 1966 Labor lost 10 and 11 seats, respectively, and made no gains. In 1969 Labor gained 20 seats and lost none.

Beginning in 1972, however, the normal pattern has been for seats to change hands in both directions. The exceptional cases were 1975 (Labor lost 28 seats and gained none), 1983 (Labor gained 22 seats and lost none), 1984 (Labor lost eight seats and gained none) and 1996 when Labor lost 33 seats and gained none. For all the 1998, 2001, 2004, 2007 and 2010 elections, seats have changed hands in both directions. The unusual nature of 2010 is the big difference with the result in 2007 when one compares the actual result (Table 26.2) with the notional result on the new boundaries in New South Wales, Queensland and Western Australia (Table 26.3). Consequently, I shall give the seat gains and losses in each of these States.

In New South Wales, Labor won 28 seats in 2007 and 26 in 2010. On an actual basis that is two losses, and one would identify the two as Bennelong and Macquarie. Only in Bennelong was a sitting Labor member defeated: Maxine McKew. If one takes the base as 30 seats, however, there were four losses: Gilmore and Macarthur, notional, and Bennelong and Macquarie, actual.

In Queensland, Labor won 15 seats in 2007 and eight in 2010. Actual losses were Bonner, Brisbane, Dawson, Flynn, Forde, Leichhardt and Longman. Additional notional losses were Dickson and Herbert. Of the new members, those in Dawson and Flynn joined the caucus of The Nationals, increasing the number of Queensland Nationals from three in 2007 to five in 2010: Dawson, Flynn, Hinkler, Maranoa and Wide Bay.

In Western Australia, the redistribution caused the Liberal seat of Swan to become notionally Labor; however, the sitting Liberal, Steve Irons, retained it. Labor lost Hasluck to the Liberal Party but Liberal Wilson Tuckey was defeated in $\mathrm{O}^{\prime}$ Connor by Tony Crook of The Nationals.

There were no changes in party numbers in South Australia or the Australian Capital Territory. In Tasmania, Labor lost Denison to the Independent Andrew Wilkie. In the Northern Territory, Labor lost Solomon to the Country Liberalsthe new member being Natasha Griggs who joined the party room of the Liberal Party. In Victoria (where there was no redistribution of seats), Labor gained La Trobe and McEwen from the Liberal Party. 
American analysts of congressional elections have a term, 'retirement slump', which refers to the average fall-off in the party's vote when the incumbent retires. I think, in addition to that, the term 'retirement loss' is appropriate for Australia. The following members of our House of Representatives retiredand saw their seat lost to another party or to an Independent: Fran Bailey in McEwen, James Bidgood in Dawson, Bob Debus in Macquarie, Duncan Kerr in Denison and Lindsay Tanner in Melbourne.

Table 26.4 shows the current state of parties of the House of Representatives. As can be seen there are five 'others': the Greens Member for Melbourne and four Independents. When their intentions were finally revealed on the afternoon of Tuesday, 7 September, it was seen that only Bob Katter in Kennedy intended to support the Coalition, the others supporting Labor. This enables me to divide Table 26.4 into two: the mining States of Queensland, Western Australia and the Northern Territory, and the non-mining States of New South Wales, Victoria, South Australia, Tasmania and the Australian Capital Territory.

The 47 seats in the mining States divide 34 for the Coalition, one for the Independent (Katter) supporting the Coalition and a miserable 12 for Labor. The 103 seats in the non-mining States divide 60 for Labor, 39 for the Coalition and the four Labor-supporting 'others'. It is clear from where the Gillard Government and the Abbott opposition get their support.

My friend Martin Gordon points out that there is an alternative way to describe the above. If the outback SA seat of Grey is excluded from 'non-mining Australia' then that populous part of the country (New South Wales, Australian Capital Territory, Victoria, Tasmania and non-outback South Australia) accounts for 102 seats, of which Labor and its supporters have 64 and the Coalition thirty-eight.

Then 'mining Australia' would be Queensland, Western Australia, Northern Territory-and Grey. So the Coalition would have 36 seats in 'mining Australia' and Labor only twelve. In Grey itself, according to Gordon (in email correspondence in 2010):

The striking thing is the swings to Liberal in Whyalla, 7.5 per cent, Port Pirie 10 per cent, Roxby Downs, 8.9 per cent, and also Andamooka and Coober Pedy. Whyalla has produced probably the best Liberal TPP vote $(5,005$ versus 6,461$)$ for a long time. In fact the state seat of Giles would only have a Labor lead of 7,858 to 8,172... The Liberal TPP vote in Stuart and Frome is very impressive also. 


\section{Analysis of House Swings}

Tables 26.7, 26.8, 26.9 and 26.10 set out the important information. Combining my look at these tables, I think the following observations can be made.

Table 26.7 The 10 Biggest Swings to Labor

\begin{tabular}{|l|l|l|c|}
\hline Rank & Seat* & AEC demographic rating & \% swing to Labor \\
\hline 1. (SS) & Kingston (Labor, SA) & Outer metropolitan & 9.5 \\
\hline 2. (SS) & Franklin (Labor, Tas.) & Outer metropolitan & 6.8 \\
\hline 3. & Lalor (Labor, Vic.) & Outer metropolitan & 6.6 \\
\hline 4. & Bass (Labor, Tas.) & Provincial & 5.7 \\
\hline 5. (SS) & Wakefield (Labor, SA) & Outer metropolitan & 5.4 \\
\hline 6. (RS) & McEwen (Liberal, Vic.) & Rural & 5.3 \\
\hline 7. (SS) & Corio (Labor, Vic.) & Provincial & 5.3 \\
\hline 8. (SS) & Braddon (Labor, Tas.) & Rural & 5.2 \\
\hline 9. (SS) & Makin (Labor, SA) & Outer metropolitan & 4.5 \\
\hline 10. & Lyons (Labor, Tas.) & Rural & 4.0 \\
\hline
\end{tabular}

SS = 'sophomore surge'

$\mathrm{RS}=$ 'retirement slump'

* The party shown is the one holding the seat before the 2010 election

Table 26.8 The 10 Biggest Swings to the Liberal-Nationals

\begin{tabular}{|l|l|l|c|}
\hline Rank & Seat* & AEC demographic rating & $\begin{array}{c}\text { \% swing to } \\
\text { Liberal-Nationals }\end{array}$ \\
\hline 1. (RS) & Fowler (Labor, NSW) & Outer metropolitan & 13.8 \\
\hline 2. & Wentworth (Liberal, NSW) & Inner metropolitan & 11.0 \\
\hline 3. & Bowman (Liberal, Qld) & Outer metropolitan & 10.4 \\
\hline 4. & Groom (Liberal, Qld) & Provincial & 10.3 \\
\hline 5. & O'Connor (Liberal, WA) & Rural & 10.2 \\
\hline 6. & Watson (Labor, NSW) & Inner metropolitan & 9.1 \\
\hline 7. & Banks (Labor, NSW) & Inner metropolitan & 8.9 \\
\hline 8. & Hinkler (Nationals, Qld) & Rural & 8.9 \\
\hline 9. & Maranoa (Nationals, Qld) & Rural & 8.8 \\
\hline 10. & Leichhardt (Labor, Qld) & Rural & 8.6 \\
\hline
\end{tabular}

$\mathrm{RS}=$ 'retirement slump'

* The party shown is the one holding the seat before the 2010 election 
First, the Liberal National Party (LNP) performed very well in Queensland and the Liberal Party performed very well in those parts of the Sydney metropolitan area with a substantial Asian population. I argue that the sacking of Kevin Rudd was the main reason for these big swings.

Second, in the Northern Territory the Country Liberal Party (CLP) candidate for the substantially Aboriginal division of Lingiari secured a big swing. The candidate, Leo Abbott, was Aboriginal. I have not yet been able to examine the detail of swings within this division. My friend Martin Gordon has, however, done a thorough analysis and he assures me the swing was entirely due to the Aboriginal polling places. In the predominantly white polling places, there was no swing at all. In addition to this good performance in Lingiari, the CLP gained Darwin-based Solomon on a much lower swing.

Third, Julia Gillard in her western suburbs of Melbourne division of Lalor and Malcolm Turnbull in his eastern suburbs of Sydney division of Wentworth gained high levels of personal voting.

Fourth, Labor performed very well in Victoria and Tasmania.

Fifth, high levels of 'sophomore surge' were recorded. These deserve a special mention. According to Wikipedia, a sophomore surge is

a term used in the political science of the US Congress that refers to an increase in votes that congressional candidates [candidates for the House of Representatives] usually receive when running for their first re-election. The phrase has been adopted in Australia by psephologist Malcolm Mackerras who is well-known for his electoral pendulums.

Under the heading 'etymology', it says the word 'sophomore' is commonly used to refer to someone in their second year of high school or college. Under the heading 'history', it says the phenomenon of sophomore surge was first noticed by political scientists in the 1960s.

The two biggest individual seat swings to Labor are both cases of sophomore surge. Otherwise, the two cases are rather different. Whereas Kingston is a case of South Australia as 'the State of sophomore surge', Franklin illustrates both retirement slump and sophomore surge. In 2007, Harry Quick retired from Franklin. The new Labor candidate, Julie Collins, was able to retain the seat. The swing to Liberal in Franklin in 2007 was, however, 3.1 per cent - the biggest swing to Liberal in Australia. So Franklin is the Australian equivalent of an American congressional district. First, there was retirement slump-but it was followed by sophomore surge. That is the typical American pattern.

South Australia is described above as 'the State of sophomore surge'. What is interesting about South Australia is that no division changed its member at 
this election. Grey, Kingston, Makin, Port Adelaide and Wakefield, however, changed their members in 2007, with Kingston, Makin and Wakefield Labor gains. In September 2008, Mayo changed its member at a by-election. In all of these six divisions, there was a swing in favour of the sitting member - the most notable cases being Kingston, Wakefield, Makin and Grey.

Table 26.9 Two-Party Preferred Votes and Swings in Each Division, 2010

\begin{tabular}{|c|c|c|c|c|c|}
\hline \multirow{2}{*}{ Division } & \multicolumn{2}{|c|}{ Votes preferring Labor } & \multicolumn{2}{|c|}{ Votes preferring Lib-Nats } & \multirow{2}{*}{$\begin{array}{c}\% \text { swing to } \\
\text { Lib-Nats }\end{array}$} \\
\hline & Votes & $\%$ & Votes & $\%$ & \\
\hline \multicolumn{6}{|c|}{ NEW SOUTH WALES } \\
\hline Banks & 43150 & 51.4 & 40719 & 48.6 & 8.9 \\
\hline Barton & 44742 & 56.9 & 33941 & 43.1 & 8.1 \\
\hline Bennelong & 40166 & 46.9 & 45518 & 53.1 & 4.5 \\
\hline Berowra & 28972 & 33.8 & 56752 & 66.2 & 6.2 \\
\hline Blaxland & 45948 & 62.2 & 27882 & 37.8 & 4.4 \\
\hline Bradfield & 27719 & 31.8 & 59397 & 68.2 & 4.3 \\
\hline Calare (n) & 35033 & 39.3 & 54209 & 60.7 & 7.3 \\
\hline Charlton & 52064 & 62.7 & 31016 & 37.3 & 0.2 \\
\hline Chifley & 50103 & 62.3 & 30268 & 37.7 & 7.3 \\
\hline Cook & 33450 & 37.3 & 56138 & 62.7 & 6.3 \\
\hline Cowper (n) & 34691 & 40.7 & 50477 & 59.3 & 8.0 \\
\hline Cunningham & 56234 & 63.2 & 32780 & 36.8 & 3.7 \\
\hline Dobell & 45551 & 55.1 & 37163 & 44.9 & -1.1 \\
\hline Eden-Monaro & 46300 & 54.2 & 39063 & 45.8 & -1.9 \\
\hline Farrer & 29434 & 35.5 & 53513 & 64.5 & 3.3 \\
\hline Fowler & 45178 & 58.8 & 31704 & 41.2 & 13.8 \\
\hline Gilmore & 38649 & 44.7 & 47850 & 55.3 & 5.7 \\
\hline Grayndler & 58789 & 70.6 & 24450 & 29.4 & 4.2 \\
\hline Greenway & 40355 & 50.9 & 38953 & 49.1 & 4.8 \\
\hline Hughes & 38688 & 44.8 & 47619 & 55.2 & 4.6 \\
\hline Hume & 36337 & 41.3 & 51679 & 58.7 & 3.4 \\
\hline Hunter (n) & 50803 & 62.5 & 30511 & 37.5 & 3.2 \\
\hline Kingsford Smith & 45249 & 55.2 & 36780 & 44.8 & 8.1 \\
\hline Lindsay & 42546 & 51.1 & 40681 & 48.9 & 5.2 \\
\hline Lyne (n) & 31902 & 37.6 & 53065 & 62.4 & 3.6 \\
\hline Macarthur & 36741 & 47.0 & 41462 & 53.0 & 3.5 \\
\hline Mackellar & 29855 & 34.3 & 57245 & 65.7 & 3.3 \\
\hline Macquarie & 42604 & 48.7 & 44801 & 51.3 & 1.5 \\
\hline McMahon & 46170 & 57.8 & 33690 & 42.2 & 6.0 \\
\hline Mitchell & 27500 & 32.8 & 56229 & 67.2 & 7.5 \\
\hline Newcastle & 51220 & 62.5 & 30744 & 37.5 & 3.4 \\
\hline
\end{tabular}


Julia 2010: The caretaker election

\begin{tabular}{|c|c|c|c|c|c|}
\hline \multirow{2}{*}{ Division } & \multicolumn{2}{|c|}{ Votes preferring Labor } & \multicolumn{2}{|c|}{ Votes preferring Lib-Nats } & \multirow{2}{*}{$\begin{array}{l}\% \text { swing to } \\
\text { Lib-Nats }\end{array}$} \\
\hline & Votes & $\%$ & Votes & $\%$ & \\
\hline New England (n) & 30265 & 33.2 & 60907 & 66.8 & 2.0 \\
\hline North Sydney & 30808 & 35.9 & 54901 & 64.1 & 8.5 \\
\hline Page (n) & 46273 & 54.2 & 39111 & 45.8 & -1.8 \\
\hline Parkes (n) & 27946 & 31.1 & 61789 & 68.9 & 5.2 \\
\hline Parramatta & 42583 & 54.4 & 35734 & 45.6 & 5.5 \\
\hline Paterson & 36804 & 44.7 & 45582 & 55.3 & 4.7 \\
\hline Reid & 41949 & 52.7 & 37679 & 47.3 & 8.2 \\
\hline Richmond (n) & 46071 & 57.0 & 34764 & 43.0 & 1.9 \\
\hline Riverina (n) & 28009 & 31.8 & 59980 & 68.2 & 3.6 \\
\hline Robertson & 43520 & 51.0 & 41821 & 49.0 & -0.9 \\
\hline Shortland & 52612 & 62.8 & 31101 & 37.2 & 1.9 \\
\hline Sydney & 53235 & 67.1 & 26142 & 32.9 & 2.3 \\
\hline Throsby & 51909 & 62.1 & 31662 & 37.9 & 4.7 \\
\hline Warringah & 31360 & 36.9 & 53612 & 63.1 & 4.3 \\
\hline Watson & 45393 & 59.1 & 31364 & 40.9 & 9.1 \\
\hline Wentworth & 30457 & 35.1 & 56219 & 64.9 & 11.0 \\
\hline Werriwa & 42740 & 56.7 & 32574 & 43.3 & 8.3 \\
\hline Total NSW & 1958077 & 48.8 & 2051241 & 51.2 & 4.8 \\
\hline \multicolumn{6}{|l|}{ VICTORIA } \\
\hline Aston & 40916 & 48.2 & 43901 & 51.8 & -3.3 \\
\hline Ballarat & 55188 & 61.7 & 34251 & 38.3 & -3.6 \\
\hline Batman & 58028 & 74.9 & 19435 & 25.1 & 1.0 \\
\hline Bendigo & 54928 & 59.5 & 37337 & 40.5 & -3.4 \\
\hline Bruce & 44603 & 58.1 & 32144 & 41.9 & 0.2 \\
\hline Calwell & 61045 & 69.7 & 26509 & 30.3 & -0.4 \\
\hline Casey & 38439 & 45.8 & 45458 & 54.2 & -1.7 \\
\hline Chisholm & 43459 & 56.1 & 33991 & 43.9 & 1.3 \\
\hline Corangamite & 47235 & 50.4 & 46464 & 49.6 & 0.4 \\
\hline Corio & 53083 & 64.2 & 29578 & 35.8 & -5.3 \\
\hline Deakin & 41927 & 52.4 & 38073 & 47.6 & -1.0 \\
\hline Dunkley & 42023 & 49.0 & 43777 & 51.0 & -3.0 \\
\hline Flinders & 37002 & 40.9 & 53499 & 59.1 & 0.9 \\
\hline Gellibrand & 61531 & 73.9 & 21732 & 26.1 & -2.4 \\
\hline Gippsland (n) & 34199 & 38.5 & 54513 & 61.5 & 5.5 \\
\hline Goldstein & 36811 & 43.5 & 47747 & 56.5 & 0.4 \\
\hline Gorton & 70705 & 72.2 & 27280 & 27.8 & -0.9 \\
\hline Higgins & 35180 & 43.3 & 46167 & 56.7 & -0.3 \\
\hline Holt & 60412 & 63.2 & 35133 & 36.8 & -1.6 \\
\hline Hotham & 50394 & 63.5 & 28966 & 36.5 & -0.5 \\
\hline
\end{tabular}


26. The Results and the Pendulum

\begin{tabular}{|c|c|c|c|c|c|}
\hline \multirow{2}{*}{ Division } & \multicolumn{2}{|c|}{ Votes preferring Labor } & \multicolumn{2}{|c|}{ Votes preferring Lib-Nats } & \multirow{2}{*}{$\begin{array}{c}\% \text { swing to } \\
\text { Lib-Nats }\end{array}$} \\
\hline & Votes & $\%$ & Votes & $\%$ & \\
\hline Indi & 33916 & 40.1 & 50755 & 59.9 & 0.7 \\
\hline Isaacs & 55721 & 61.0 & 35594 & 39.0 & -3.3 \\
\hline Jagajaga & 52868 & 61.5 & 33075 & 38.5 & -2.5 \\
\hline Kooyong & 34508 & 42.5 & 46779 & 57.5 & -2.0 \\
\hline La Trobe & 45308 & 50.9 & 43689 & 49.1 & -1.4 \\
\hline Lalor & 74452 & 72.1 & 28736 & 27.9 & -6.6 \\
\hline Mallee (n) & 20842 & 25.6 & 60611 & 74.4 & 3.1 \\
\hline Maribyrnong & 51193 & 66.9 & 25379 & 33.1 & -1.5 \\
\hline McEwen & 58144 & 55.3 & 46963 & 44.7 & -5.3 \\
\hline McMillan & 38731 & 45.6 & 46229 & 54.4 & -0.4 \\
\hline Melbourne & 65473 & 73.3 & 23854 & 26.7 & -1.0 \\
\hline Melbourne Ports & 48819 & 57.6 & 36002 & 42.4 & -0.4 \\
\hline Menzies & 33811 & 41.3 & 48102 & 58.7 & 2.7 \\
\hline Murray & 23882 & 29.7 & 56666 & 70.3 & 2.1 \\
\hline Scullin & 57355 & 72.2 & 22025 & 27.8 & -1.4 \\
\hline Wannon & 35554 & 42.7 & 47697 & 57.3 & -0.2 \\
\hline Wills & 61297 & 72.6 & 23091 & 27.4 & -0.2 \\
\hline Total Victoria & 1758982 & 55.3 & 1421202 & 44.7 & -1.0 \\
\hline \multicolumn{6}{|l|}{ QUEENSLAND } \\
\hline Blair & 39814 & 54.2 & 33595 & 45.8 & 2.7 \\
\hline Bonner & 38765 & 47.2 & 43400 & 52.8 & 7.4 \\
\hline Bowman & 32455 & 39.6 & 49490 & 60.4 & 10.4 \\
\hline Brisbane & 39609 & 48.9 & 41440 & 51.1 & 5.7 \\
\hline Capricornia (n) & 43150 & 53.7 & 37230 & 46.3 & 8.4 \\
\hline Dawson (n) & 39455 & 47.6 & 43494 & 52.4 & 5.0 \\
\hline Dickson & 36549 & 44.9 & 44902 & 55.1 & 5.9 \\
\hline Fadden & 26356 & 35.8 & 47236 & 64.2 & 3.8 \\
\hline Fairfax & 34034 & 43.1 & 45032 & 56.9 & 4.0 \\
\hline Fisher & 33784 & 45.9 & 39868 & 54.1 & 0.6 \\
\hline Flynn (n) & 37086 & 46.4 & 42806 & 53.6 & 5.8 \\
\hline Forde & 33987 & 48.4 & 36271 & 51.6 & 5.0 \\
\hline Griffith & 47007 & 58.5 & 33405 & 41.5 & 3.9 \\
\hline Groom & 26589 & 31.5 & 57912 & 68.5 & 10.3 \\
\hline Herbert & 37797 & 47.8 & 41221 & 52.2 & 2.2 \\
\hline Hinkler (n) & 31993 & 39.6 & 48770 & 60.4 & 8.9 \\
\hline Kennedy (n) & 31106 & 38.1 & 50616 & 61.9 & 4.7 \\
\hline Leichhardt & 36273 & 45.5 & 43539 & 54.5 & 8.6 \\
\hline Lilley & 46234 & 53.2 & 40711 & 46.8 & 4.8 \\
\hline Longman & 36277 & 48.1 & 39173 & 51.9 & 3.8 \\
\hline
\end{tabular}


Julia 2010: The caretaker election

\begin{tabular}{|c|c|c|c|c|c|}
\hline \multirow{2}{*}{ Division } & \multicolumn{2}{|c|}{ Votes preferring Labor } & \multicolumn{2}{|c|}{ Votes preferring Lib-Nats } & \multirow{2}{*}{$\begin{array}{l}\% \text { swing to } \\
\text { Lib-Nats }\end{array}$} \\
\hline & Votes & $\%$ & Votes & $\%$ & \\
\hline McPherson & 31004 & 39.7 & 47044 & 60.3 & 1.6 \\
\hline Maranoa (n) & 23625 & 27.1 & 63520 & 72.9 & 8.8 \\
\hline Moncrieff & 24612 & 32.5 & 51103 & 67.5 & 3.7 \\
\hline Moreton & 41447 & 51.1 & 39612 & 48.9 & 4.9 \\
\hline Oxley & 39894 & 55.8 & 31640 & 44.2 & 5.6 \\
\hline Petrie & 40097 & 52.5 & 36267 & 47.5 & 1.7 \\
\hline Rankin & 44289 & 55.4 & 35640 & 44.6 & 6.3 \\
\hline Ryan & 38138 & 42.8 & 50896 & 57.2 & 6.0 \\
\hline Wide Bay (n) & 28029 & 34.4 & 53484 & 65.6 & 7.2 \\
\hline Wright & 30049 & 39.9 & 45358 & 60.1 & 6.4 \\
\hline Total Queensland & 1069504 & 44.9 & 1314675 & 55.1 & 5.6 \\
\hline \multicolumn{6}{|c|}{ WESTERN AUSTRALIA } \\
\hline Brand & 41610 & 53.3 & 36418 & 46.7 & 2.7 \\
\hline Canning & 38303 & 47.8 & 41818 & 52.2 & -2.2 \\
\hline Cowan & 34992 & 43.7 & 45062 & 56.3 & 5.0 \\
\hline Curtin & 27669 & 33.8 & 54158 & 66.2 & 2.9 \\
\hline Durack & 26155 & 36.3 & 45843 & 63.7 & 6.0 \\
\hline Forrest & 33257 & 41.3 & 47343 & 58.7 & 3.3 \\
\hline Fremantle & 45858 & 55.7 & 36478 & 44.3 & 3.4 \\
\hline Hasluck & 40774 & 49.4 & 41722 & 50.6 & 1.4 \\
\hline Moore & 31901 & 38.8 & 50302 & 61.2 & 2.3 \\
\hline O'Connor & 22029 & 27.0 & 59555 & 73.0 & 10.2 \\
\hline Pearce & 32349 & 41.1 & 46292 & 58.9 & 1.2 \\
\hline Perth & 44815 & 55.9 & 35379 & 44.1 & 2.1 \\
\hline Stirling & 35832 & 44.4 & 44775 & 55.6 & 4.3 \\
\hline Swan & 37710 & 47.5 & 41729 & 52.5 & 2.8 \\
\hline Tangney & 31607 & 37.7 & 52266 & 62.3 & 2.5 \\
\hline Total WA & 524861 & 43.6 & 679140 & 56.4 & 3.1 \\
\hline \multicolumn{6}{|c|}{ SOUTH AUSTRALIA } \\
\hline Adelaide & 50164 & 57.7 & 36793 & 42.3 & 0.8 \\
\hline Barker & 34992 & 37.1 & 59278 & 62.9 & 3.4 \\
\hline Boothby & 42042 & 49.3 & 43317 & 50.7 & -2.2 \\
\hline Grey & 34373 & 38.8 & 54119 & 61.2 & 6.7 \\
\hline Hindmarsh & 49698 & 55.7 & 39526 & 44.3 & -0.7 \\
\hline Kingston & 58695 & 63.9 & 33139 & 36.1 & -9.5 \\
\hline Makin & 53014 & 62.2 & 32219 & 37.8 & -4.5 \\
\hline Mayo & 39201 & 42.7 & 52702 & 57.3 & 0.3 \\
\hline Port Adelaide & 63295 & 70.0 & 27084 & 30.0 & -0.3 \\
\hline Sturt & 41113 & 46.6 & 47172 & 53.4 & 2.5 \\
\hline Wakefield & 54528 & 61.9 & 33485 & 38.1 & -5.4 \\
\hline Total SA & 521115 & 53.2 & 458834 & 46.8 & -0.8 \\
\hline
\end{tabular}




\begin{tabular}{|c|c|c|c|c|c|}
\hline \multirow{2}{*}{ Division } & \multicolumn{2}{|c|}{ Votes preferring Labor } & \multicolumn{2}{|c|}{ Votes preferring Lib-Nats } & \multirow{2}{*}{$\begin{array}{l}\% \text { swing to } \\
\text { Lib-Nats }\end{array}$} \\
\hline & Votes & $\%$ & Votes & $\%$ & \\
\hline \multicolumn{6}{|l|}{ TASMANIA } \\
\hline Bass & 37165 & 56.7 & 28337 & 43.3 & -5.7 \\
\hline Braddon & 37650 & 57.5 & 27855 & 42.5 & -5.2 \\
\hline Denison & 42692 & 65.8 & 22167 & 34.2 & -0.5 \\
\hline Franklin & 39856 & 60.8 & 25675 & 39.2 & -6.8 \\
\hline Lyons & 40959 & 62.3 & 24796 & 37.7 & -4.0 \\
\hline Total Tasmania & 198322 & 60.6 & 128830 & 39.4 & -4.4 \\
\hline \multicolumn{6}{|l|}{ ACT } \\
\hline Canberra & 66335 & 59.1 & 45821 & 40.9 & 2.7 \\
\hline Fraser & 71613 & 64.2 & 39928 & 35.8 & 0.9 \\
\hline Total ACT & 137948 & 61.7 & 85749 & 38.3 & 1.7 \\
\hline \multicolumn{6}{|c|}{ NORTHERN TERRITORY } \\
\hline Lingiari & 23051 & 53.7 & 19876 & 46.3 & 7.5 \\
\hline Solomon & 24585 & 48.3 & 26371 & 51.7 & 1.9 \\
\hline $\begin{array}{l}\text { Total Northern } \\
\text { Territory }\end{array}$ & 47636 & 50.7 & 46247 & 49.3 & 4.7 \\
\hline Total Australia & 6216445 & 50.1 & 6185918 & 49.9 & 2.6 \\
\hline
\end{tabular}

\section{Fairness of Our Electoral Boundaries}

It is clear that Labor performed very well in Victoria and Tasmania and quite well in South Australia and the Australian Capital Territory. It is equally clear that the Coalition performed very well in the mining jurisdictions of Queensland, Western Australia and the Northern Territory. That leaves our most populous State of which the question must now be asked: who won in New South Wales?

Before I come to New South Wales, I want to give a brief consideration to the Australian Capital Territory. I argue that the swings to Liberal in both divisions were not real swings at all. They were cases of retirement slump, since both seats changed their Labor members through retirement. My basis for this assertion lies in the Senate vote. In 2007 Gary Humphries (Liberal) was elected to the second Senate seat with a quota in his own right. No distribution of preferences was necessary. In 2010, in contrast, he did not receive a quota on the first count. Before he could be elected, the surplus of Kate Lundy (Labor) needed to be distributed, then two other candidates (there were nine in all) needed to be excluded before Humphries was elected.

In New South Wales, Labor won in terms of seats but the Coalition won the twoparty preferred vote (see Tables 26.4 and 26.9). That raises this question: can it be argued that the electoral boundaries in New South Wales were gerrymandered in favour of Labor? To so argue would go wholly against everything I have 
asserted about our federal redistributions since the electoral reforms of 1983 and 1984. I have asserted that the traditional pattern of boundaries being drawn in favour of the party in power would not happen again after those reforms.

In the case of this election, I point out that Labor won 50.1 per cent of the Australia-wide two-party preferred vote and the Coalition 49.9 per cent. The consequence in seats was that 76 recorded two-party preferred majorities in favour of the Coalition and 74 for Labor. Therefore, it is absurd to suggest that the boundaries were, in any way, loaded in favour of Labor. Quite the reverse! It is true that on my new pendulum the 76-74 distribution goes the other way; that is explained by Lyne and New England. As can be clearly seen from Table 26.9, Lyne and New England were easily won by The Nationals in terms of the two-party preferred vote. Their Independent members, however, decided to keep Labor in office.

Table 26.10 Median Seats on Mackerras Pendulum and Overall Labor Percentages Required for Government

\begin{tabular}{|c|c|c|c|c|c|}
\hline $\begin{array}{l}\text { Election } \\
\text { year }\end{array}$ & Median seat & $\begin{array}{c}\% \text { swing } \\
\text { needed }\end{array}$ & $\begin{array}{l}\text { Seat } \\
\text { held? }\end{array}$ & $\begin{array}{l}\text { Coalition two- } \\
\text { party preferred } \\
\text { vote } \% \text { at } \\
\text { previous election }\end{array}$ & $\begin{array}{c}\text { Labor } \% \\
\text { required } \\
\text { on uniform } \\
\text { swing }\end{array}$ \\
\hline 1961 & Bowman (Liberal, Qld) & 6.2 & No & 54.1 & 52.1 \\
\hline 1963 & Maribyrnong (Liberal, Vic.) & 0.9 & Yes & 49.5 & 51.4 \\
\hline 1966 & Robertson (Liberal, NSW) & 3.9 & Yes & 52.6 & 51.3 \\
\hline 1969 & Forrest (Liberal, WA) & 7.8 & No & 56.9 & 50.9 \\
\hline 1972 & Griffith (Liberal, Qld) & 1.6 & Yes & 49.8 & 51.8 \\
\hline 1974 & Mitchell (Labor, NSW) & 1.3 & No & 47.3 & 51.4 \\
\hline 1975 & Isaacs (Labor, Vic.) & 0.5 & No & 48.3 & 51.2 \\
\hline 1977 & Kingston (Liberal, SA) & 6.6 & Yes & 55.7 & 50.9 \\
\hline 1980 & Fadden (Liberal, Qld) & 6.1 & Yes & 54.6 & 51.5 \\
\hline 1983 & Bendigo (Liberal, Vic.) & 1.4 & No & 50.4 & 51.0 \\
\hline 1984 & Dunkley (Labor, Vic.) & 3.1 & Yes & 46.8 & 50.1 \\
\hline 1987 & Lowe (Labor, NSW) & 2.3 & No & 48.2 & 49.5 \\
\hline 1990 & Aston (Labor, Vic.) & 2.6 & No & 49.2 & 48.2 \\
\hline 1993 & Cowan (Labor, WA) & 0.9 & No & 50.1 & 49.0 \\
\hline 1996 & Gilmore (Labor, NSW) & 0.5 & No & 48.6 & 50.9 \\
\hline 1998 & Parramatta (Liberal, NSW) & 3.9 & Yes & 53.6 & 50.3 \\
\hline 2001 & Moreton (Liberal, Qld) & 0.6 & Yes & 49.0 & 51.6 \\
\hline 2004 & Eden-Monaro (Liberal, NSW) & 1.7 & Yes & 50.9 & 50.8 \\
\hline 2007 & Bennelong (Liberal, NSW) & 4.0 & No & 52.7 & 51.3 \\
\hline 2010 & Longman (Labor, Qld) & 1.7 & No & 47.3 & 51.0 \\
\hline 2013 & Greenway (Labor, NSW) & 0.9 & $?$ & 49.9 & 49.2 \\
\hline
\end{tabular}


Table 26.10 is entitled 'Median Seats on Mackerras Pendulum and Overall Labor Percentages Required for Government'; however, I faced a dilemma here. On the pendulum as actually published, the median seat is Greenway (Labor, NSW) where the Liberal Party needs a swing of 0.9 per cent to regain the seat. That means the overall share for Labor to govern is shown as 49.2 per cent. Those statistics only apply, however, because Lyne and New England have changed sides on the pendulum without having changed their voting patterns. If The Nationals had won both these seats then the Coalition number would have been 76 and the median seat would have been shown as Boothby (Liberal, SA), needing a swing of 0.8 per cent for Labor to win. That being so, the overall share needed for Labor to govern on the uniform-swing model would have been shown as 50.7 per cent-very close to the figure shown in the row above: the even 51 per cent.

Coming back to New South Wales, the argument to suppose a Labor gerrymander would lie in the very economical margins secured by Labor in Greenway, Robertson, Lindsay, Banks and Reid. Here I would say that good old-fashioned luck had a lot to do with those wins. I estimate the 'donkey vote' at this election in those seats to have been worth 1.2 per cent of the formal vote. It happens that Labor had the benefit of the ballot-paper draw in all five seats. If the draw had gone the other way, I think Labor would still have retained Reid but it would have lost Greenway, Robertson, Lindsay and Banks.

When I write of a 'donkey vote' in those seats to have been worth 1.2 per cent, I should mention the basis of that estimate. I went through all the preference distributions in seats in the Newcastle-Sydney-Wollongong conurbation and came up with that estimate. The single most interesting case is Reid where Christian Democratic Party (CDP) voters broke the 'how-to-vote' card that preferenced the Liberal Party. There were five candidates in Reid with the CDP first, Labor second, Greens third, Liberal fourth and Carolyn Kennett of the Socialist Equity Party bottom on the ballot paper. Kennett was first eliminated and CDP second. The CDP candidate, Bill Shailer, had 2445 primary votes and gained 167 from the Kennett distribution. His 2612 votes were distributed 1197 to Labor, 974 to Liberal and 441 to the Greens. My claim that Labor's Banks win was based on the 'donkey vote' is based on my analysis of the Greens distribution in that seat where they were on the top of the ballot paper and Labor was higher than Liberal. In Greenway and Lindsay the Labor candidate was actually on the top of the ballot paper.

Reference was made above to South Australia as 'the State of sophomore surge'. It is worth considering New South Wales in that context. Here I see a contrast between metropolitan Sydney and the country. In the north-western inner-metropolitan seat of Bennelong, Maxine McKew conspicuously failed to get any sophomore surge. I attribute that to her loss of Asian support- 
a consequence of the dumping of Kevin Rudd. Also the unpopularity of the State Labor Government had the effect that she gained nothing from Julia Gillard's promise to build the Parramatta-Epping railway. McKew's fate contrasts greatly with that of Janelle Saffin in Page and Mike Kelly in Eden-Monaro. Both these country Labor members gained the benefit of sophomore surge.

\section{The Senate Election}

Given that the Australian Senate electoral system is semi-proportional rather than one of proportional representation, it is not surprising that one needs to go back to 1993 to find a truly proportional result. Indeed, depending on how one reads the Gallagher least-squares indexes of disproportionality, it can be argued that one needs to go back to 1987 to find a truly proportional resultand 1987 was a double-dissolution election in which one would expect the level of proportionality to be higher.

At this 2010 election, the Coalition won 18 seats, Labor 15, the Greens six and the Democratic Labor Party one seat-in Victoria. Table 26.12 sets out how these numbers affect the distribution of the seats in the whole Senate from July 2011. Converting percentages of votes into percentages of seats, I find that the Coalition's 38.6 per cent of votes becomes 45 per cent of seats, Labor's 35.1 per cent of votes becomes 37.5 per cent of seats and 13.1 per cent of votes for the Greens becomes 15 per cent of seats. So the big three parties are overrepresented. In contrast, the category 'other' secured 13.2 per cent of the votes and only 2.5 per cent of the seats.

The senators elected in August 2010 have, from July 2011, replaced the senators elected in October 2004. For that reason it is sensible to compare the votes of 2004 and 2010. Whereas one speaks of a 'swing to the right' in the House of Representatives election (comparing 2010 with 2007), one speaks of a 'swing to the left' in the Senate election by comparing 2010 with 2004. That there was a swing to the left is made clear from Tables 26.13 and 26.14.

The seats followed the votes. In all of Queensland, Victoria and Tasmania, the left gained a seat from the right in 2010. In Queensland and Victoria that meant converting a four-two right-left distribution in 2004 into a three-three distribution in 2010, with the Greens gaining a seat in each State. In Tasmania it meant the Labor Party gaining a seat from the Liberal Party.

Can we, however, compare 2007 and 2010 and assert that the swing was to the left? Can we assert the swing was to the right? The answer is in the negative for both questions. All we can say is that the result in Tasmania was the same on each occasion: three Labor, two Liberal and one for the Greens. In the five 
mainland States, the distribution between left and right was three-three, both in 2007 and in 2010. The difference is simply that Labor performed better in 2007 and the Greens in 2010.

At the 2013 election can the Greens increase their Senate numbers yet again? Probably - but there is no certainty. If that election follows a double dissolution, the Greens would surely lose a seat in South Australia - and possibly in Western Australia also. If there is a premature House-only election then the half-Senate election might be deferred to May 2014. My prediction, however, is that we shall have a House of Representatives plus half-Senate election in October 2013. The Greens would have only three senators coming up for re-election-one each in Tasmania, Western Australia and South Australia. In that case it would be likely they could increase their numbers yet again.

Table 26.11 State of Parties in the Senate from 1 July 2008

\begin{tabular}{|l|c|c|c|c|c|c|c|c|c|}
\hline Party & NSW & Vic. & Qld & WA & SA & Tas. & ACT & NT & Total \\
\hline Labor & 6 & 5 & 5 & 4 & 5 & 5 & 1 & 1 & 32 \\
\hline Liberal & 4 & 6 & 5 & 6 & 5 & 5 & 1 & - & 32 \\
\hline Nationals & 2 & - & 2 & - & - & - & - & 1 & 5 \\
\hline Greens & - & - & - & 2 & 1 & 2 & - & - & 5 \\
\hline Independent & - & - & - & - & 1 & - & - & - & 1 \\
\hline Family First & - & 1 & - & - & - & - & - & - & 1 \\
\hline Total & 12 & 12 & 12 & 12 & 12 & 12 & 2 & 2 & 76 \\
\hline
\end{tabular}

Table 26.12 State of Parties in the Senate from 1 July 2011

\begin{tabular}{|l|c|c|c|c|c|c|c|c|c|}
\hline Party & NSW & Vic. & Qld & WA & SA & Tas. & ACT & NT & Total \\
\hline Labor & 5 & 5 & 5 & 4 & 4 & 6 & 1 & 1 & 31 \\
\hline Liberal & 4 & 4 & 4 & 6 & 5 & 4 & 1 & - & 28 \\
\hline Nationals & 2 & 1 & 2 & - & - & - & - & 1 & 6 \\
\hline Greens & 1 & 1 & 1 & 2 & 2 & 2 & - & - & 9 \\
\hline Independent & - & - & - & - & 1 & - & - & - & 1 \\
\hline $\begin{array}{l}\text { Democratic } \\
\text { Labor Party }\end{array}$ & - & 1 & - & - & - & - & - & - & 1 \\
\hline Total & 12 & 12 & 12 & 12 & 12 & 12 & 2 & 2 & 76 \\
\hline
\end{tabular}


Julia 2010: The caretaker election

Table 26.13 Labor and Liberal-Country Party-Nationals Senate

Percentages

\begin{tabular}{|c|c|c|c|}
\hline Election & Labor & Lib.-CP-Nats & Excess Lib.-CP-Nats over Labor \\
\hline 1949 & 44.9 & 50.4 & 5.5 \\
\hline 1951 & 45.9 & 49.7 & 3.8 \\
\hline 1953 & 50.6 & 44.4 & -6.2 \\
\hline 1955 & 40.6 & 48.7 & 8.1 \\
\hline 1958 & 42.8 & 45.2 & 2.4 \\
\hline 1961 & 44.7 & 42.1 & -2.6 \\
\hline 1964 & 44.7 & 45.7 & 1.0 \\
\hline 1967 & 45.0 & 42.8 & -2.2 \\
\hline 1970 & 42.2 & 38.2 & -4.0 \\
\hline 1974 & 47.3 & 43.9 & -3.4 \\
\hline 1975 & 40.9 & 51.7 & 10.8 \\
\hline 1977 & 36.8 & 45.6 & 8.8 \\
\hline 1980 & 42.3 & 43.5 & 1.2 \\
\hline 1983 & 45.5 & 39.9 & -5.6 \\
\hline 1984 & 42.2 & 39.5 & -2.7 \\
\hline 1987 & 42.8 & 42.0 & -0.8 \\
\hline 1990 & 38.4 & 41.9 & 3.5 \\
\hline 1993 & 43.5 & 43.0 & -0.5 \\
\hline 1996 & 36.2 & 44.0 & 7.8 \\
\hline 1998 & 37.3 & 37.7 & 0.4 \\
\hline 2001 & 34.3 & 41.8 & 7.5 \\
\hline 2004 & 35.0 & 45.1 & 10.1 \\
\hline 2007 & 40.3 & 39.9 & -0.4 \\
\hline 2010 & 35.1 & 38.6 & 3.5 \\
\hline Average & 41.6 & 43.6 & 2.0 \\
\hline
\end{tabular}

Note: Cases where excess is 10 per cent or more are shown in bold. 
Table 26.14 Greens Performances, 2007 and 2010

\begin{tabular}{|l|c|c|c|c|c|c|c|}
\hline \multirow{2}{*}{\begin{tabular}{l} 
Jurisdiction \\
\cline { 3 - 8 }
\end{tabular}} & Senators & \multicolumn{2}{|c|}{ Half-Senate election 2007} & \multicolumn{3}{|c|}{ Half-Senate election 2010} \\
\cline { 2 - 8 } $\begin{array}{l}\text { Australian } \\
\text { Capital } \\
\text { Territory }\end{array}$ & 2 & 48384 & $\%$ & Total formal & Votes & $\%$ & Total formal \\
\hline Tasmania & 6 & $59254^{*}$ & 18.1 & 326846 & $67016^{*}$ & 20.3 & 330691 \\
\hline Victoria & 6 & 320759 & 10.1 & 3182369 & $471317^{*}$ & 14.6 & 3218751 \\
\hline $\begin{array}{l}\text { Western } \\
\text { Australia }\end{array}$ & 6 & $111813^{*}$ & 9.3 & 1202750 & $172327^{*}$ & 14.0 & 1234219 \\
\hline $\begin{array}{l}\text { Northern } \\
\text { Territory }\end{array}$ & 2 & 8870 & 8.8 & 100569 & 13105 & 13.6 & 96687 \\
\hline $\begin{array}{l}\text { South } \\
\text { Australia }\end{array}$ & 6 & $65322^{*}$ & 6.5 & 1006809 & $134287^{*}$ & 13.3 & 1009578 \\
\hline Queensland & 6 & 177063 & 7.3 & 2418907 & $312804^{*}$ & 12.8 & 2450511 \\
\hline $\begin{array}{l}\text { New South } \\
\text { Wales }\end{array}$ & 6 & 353286 & 8.4 & 4193234 & $443913^{*}$ & 10.7 & 4152524 \\
\hline Total & 40 & 1144751 & 9.0 & 12656805 & 1667315 & 13.1 & 12722233 \\
\hline
\end{tabular}

* A senator was elected on this vote. In all there were three in 2007 and six in 2010, for a total of nine from 1 July 2011

Table 26.15 Winners and Losers for Last Senate Places, 2010

\begin{tabular}{|c|c|c|c|c|c|}
\hline \multirow[b]{2}{*}{ State } & \multirow[b]{2}{*}{ Quota } & \multicolumn{2}{|l|}{ Last winners } & \multicolumn{2}{|l|}{ Best losers } \\
\hline & & Fifth & Sixth & Best & Second best \\
\hline NSW & 593123 & $\begin{array}{l}\text { Fiona Nash } \\
\text { (Nationals) }\end{array}$ & $\begin{array}{l}\text { Lee Rhiannon } \\
\text { (Greens) }\end{array}$ & $\begin{array}{l}\text { Steve Hutchins } \\
\text { (Labor) }\end{array}$ & $\begin{array}{l}\text { Glenn Druery } \\
\text { (Liberal } \\
\text { Democrats) }\end{array}$ \\
\hline Vic. & 459822 & $\begin{array}{l}\text { Bridget } \\
\text { McKenzie } \\
\text { (Nationals) }\end{array}$ & $\begin{array}{l}\text { John Madigan } \\
\text { (DLP) }\end{array}$ & $\begin{array}{l}\text { Antony Thow } \\
\text { (Labor) }\end{array}$ & $\begin{array}{l}\text { Julian McGauran } \\
\text { (Liberal) }\end{array}$ \\
\hline Qld & 350074 & $\begin{array}{l}\text { Larissa Waters } \\
\text { (Greens) }\end{array}$ & $\begin{array}{l}\text { Brett Mason } \\
\text { (Liberal) }\end{array}$ & $\begin{array}{l}\text { Keith Douglas } \\
\text { (Aust. Fishing \& } \\
\text { Lifestyle Party) }\end{array}$ & $\begin{array}{l}\text { Desiree Gibson } \\
\text { (Aust. Sex Party) }\end{array}$ \\
\hline WA & 176318 & $\begin{array}{l}\text { Judith Adams } \\
\text { (Liberal) }\end{array}$ & $\begin{array}{l}\text { Rachel Siewert } \\
\text { (Greens) }\end{array}$ & $\begin{array}{l}\text { John McCourt } \\
\text { (Nationals) }\end{array}$ & $\begin{array}{l}\text { Wendy Perdon } \\
\text { (Labor) }\end{array}$ \\
\hline SA & 144226 & $\begin{array}{l}\text { Penny Wright } \\
\text { (Greens) }\end{array}$ & $\begin{array}{l}\text { David Fawcett } \\
\text { (Liberal) }\end{array}$ & $\begin{array}{l}\text { Dana Wortley } \\
\text { (Labor) }\end{array}$ & $\begin{array}{l}\text { Bob Day (Family } \\
\text { First) }\end{array}$ \\
\hline Tas. & 47242 & $\begin{array}{l}\text { Stephen Parry } \\
\text { (Liberal) }\end{array}$ & $\begin{array}{l}\text { Lisa Singh } \\
\text { (Labor) }\end{array}$ & $\begin{array}{l}\text { Guy Barnett } \\
\text { (Liberal) }\end{array}$ & $\begin{array}{l}\text { Peter Whish- } \\
\text { Wilson (Greens) }\end{array}$ \\
\hline
\end{tabular}


Julia 2010: The caretaker election

\section{References}

Mackerras, Malcolm. 1984. 'The Early Dissolution of the House of Representatives'. Politics 19(1): 73-84.

Smith, Arthur Norman. 1933. Thirty Years: The Commonwealth of Australia, 1901-1931. Melbourne: Brown, Prior.

Whitington, Don. 1954. The House will Divide. Melbourne: Lansdowne Press. 